\title{
UNCERTAINTY ANALYSIS OF PRIMARY RESOURCE SAVINGS AT COGENERATION
}

\author{
I. Veidenbergs, D. Blumberga, \\ F. Romagnoli, E. Vīgants, M. Rošā \\ Riga Technical University, Institute of Energy Systems and Environment, \\ 1 Kronvalda Blvd., Riga, LV-1010, LATVIA \\ e-pasts: dagnija.blumberga@rtu.lv
}

\begin{abstract}
The article provides the uncertainty analysis for electricity and heat energy production measurements at a cogeneration plant. It is analysed how the uncertainty in the input data affects the uncertainty in the data on primary resource savings. In the work, the standard uncertainties have been estimated for both data sets. The uncertainty budget is defined for determination of the primary energy resource savings.

Key words: electricity production, heat energy production, standard uncertainty, budget of uncertainty, efficiency, natural gas.
\end{abstract}

\section{INTRODUCTION}

The information gathered from the results of measurements and the relevant calculations could be considered complete only when the values obtained have been reported together with the indication of the uncertainty range for these values; this would mean that an actual value is within the indicated range of uncertainty. Uncertainty is termed the expanded uncertainty when the level of confidence equals $95 \%[1]$.

The term 'uncertainty' needs clarification because in the Baltic countries until the year of 1993, and in Russia until 1999 [2] the term 'error' was used instead of 'uncertainty'. Thus, all the instruments and methods for verification and control and the procedures for conduction of measurements and calculations during those periods were applied in compliance with the concept of error and not with that of uncertainty.

The concept of measurement uncertainty and a unified calculation procedure were introduced in guidelines [3], which establish that the measurement uncertainty is a parameter connected with the measurement results and describes the dispersion of the value that can justifiably be related to the measured quantity. In the guidelines, the term uncertainty is described in two ways - narrow and broad ones. In the narrow way, uncertainty is an incidental quantity which contains information on the sources of uncertainty in the measuring process at the level currently known. The broader concept of uncertainty takes into account that not all sources of uncertainty may be identified, or known sources might not be evaluated fully due to lack of information. This broader concept of uncertainty also implies that improvement of the measuring process would reduce the uncertainty level. This 
concept is connected with critical thinking and deep professional knowledge about the parameters to be measured and the measurements to be taken. The quality of the result is undoubtedly dependent on the understanding of the measuring process and its critical analysis.

There is an essential difference between the concepts of uncertainty and error, whereby an error in measurement is a conceptual quantity the value of which is unknown, since the true value of the measured quantity is not known [4]. Instead of using the true value, there are used its estimate, a reference or a standard value, each of them having their own mistakes. In practice many sources of uncertainty in measurements are possible. Below, an uncertainty analysis is given for the measurements of a cogeneration plant's operation data.

\section{THE COMPANY'S SCHEME OF MEASUREMENTS AT THE PLANT AND DESCRIPTION OF THE MEASURING DEVICES}

At the considered cogeneration plant a continuous monitoring is conducted to control its operating conditions and to collect the report data (once every 24 hours). For this purpose the plant is equipped with the necessary measuring devices (Fig. 1).

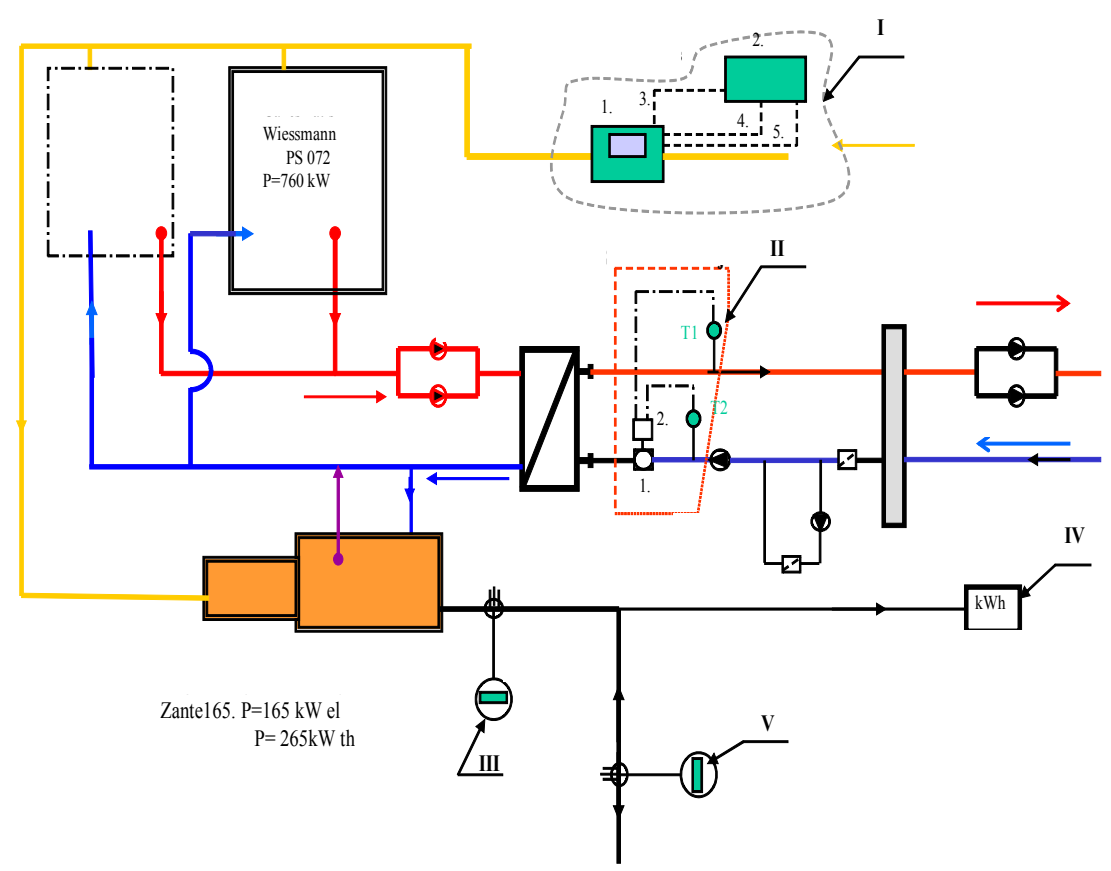

Fig. 1. The measurement scheme of the cogeneration plant.

At the plant, the gas (I), heat energy (I) and three electricity (III, IV, V) meters are installed. Meter III measures the total electricity produced at the cogeneration plant. A portion of this energy is directly supplied to consumers (measured by meter IV). The cogeneration plant is connected to the electricity grid and the corresponding electricity exchange is measured by meter $\mathrm{V}$. The data from meter III are used for the uncertainty analysis. All measuring devices employed at the plant have been verified. 
In the specifications of measuring devices the following precision values are indicated:

- gas consumption $\pm 1 \mathrm{~nm}^{3}$;

- heat consumption $\pm 0.1 \mathrm{GJ}$ or $\pm 0.028 \mathrm{MWh}$;

- electricity consumption $\pm 0.001 \mathrm{MWh}$.

\section{THE DEPENDENCE OF PRIMARY RESOURCE SAVINGS ON THE INPUT DATA}

The formula used for determination of the primary resource savings in the case of natural gas is:

$$
\delta Q_{P E}=\left(1-\frac{V \cdot Q_{z}^{d}}{\frac{W}{0.45}+\frac{Q}{0.9}}\right),
$$

where $V$ is the natural gas consumption, $\mathrm{m}^{3}$;

$Q_{z}^{d}$ is its calorific value, $\mathrm{MWh} / \mathrm{m}^{3}$;

$Q$ is the heat energy produced at the cogeneration plant, MWh;

$W$ is the electricity produced at the cogeneration plant, MWh.

Formula (1) connects the primary resource savings with the parameters measured at the plant and serves to identify the uncertainty sources. The main of them are:

- gas consumption measurements;

- heat energy measurements;

- electricity measurements.

Since the measurements are made using the verified equipment with a known precision, the level of uncertainty is determined by the type B uncertainty determination method [5].

\section{THE STANDARD UNCERTAINTY OF PRIMARY RESOURCE SAVINGS}

The measurement uncertainty is a parameter which describes the dispersion of measurement results. Uncertainties of the kind are evaluated by the standard uncertainty. For example, the standard uncertainty for a repeatedly measured random variable (type A uncertainty) is determined as the square root of the measurement dispersion. This is valid for direct measurements. In indirect measurements for calculation of the standard uncertainty a model function is used.

If there is no correlation between the standard uncertainties of input data (gas consumption, produced heat energy and electricity) then the squared standard uncertainty of the primary resource savings is calculated as

$$
u_{c}^{2}\left(\delta Q_{P E}\right)=\left(\frac{\partial \delta Q_{P E}}{\partial V} u(V)\right)^{2}+\left(\frac{\partial \delta Q_{P E}}{\partial W} u(W)\right)^{2}+\left(\frac{\partial \delta Q_{P E}}{\partial Q} u(Q)\right)^{2},
$$


where $\frac{\partial \delta Q_{P E}}{\partial V} ; \frac{\partial \delta Q_{P E}}{\partial W} ; \frac{\partial \delta Q_{P E}}{\partial Q}$ are the sensitivity coefficients of the corresponding parameters $\left(C_{i}\right)$;

$u(V) ; u(W) ; u(Q)$ are the standard uncertainties of the corresponding parameters.

The formulas for calculating the sensitivity coefficients of the input data follow from Eq. (1) as the partial derivatives of the corresponding parameters:

$$
\begin{aligned}
& C_{V}=\frac{\partial \delta Q_{P E}}{\partial V}=-\frac{Q_{z}^{d}}{\frac{W}{0.45}+\frac{Q}{0.9}} ; \\
& C_{W}=\frac{\partial \delta Q_{P E}}{\partial W}=\frac{V \cdot Q_{z}^{d}}{0.45\left(\frac{W}{0.45}+\frac{Q}{0.9}\right)^{2}} ; \\
& C_{Q}=\frac{\partial \delta Q_{P E}}{\partial Q}=\frac{V \cdot Q_{z}^{d}}{0.9\left(\frac{W}{0.45}+\frac{Q}{0.9}\right)^{2}} .
\end{aligned}
$$

The calculated sensitivity coefficients are shown in Table 1 . For each parameter the contribution of the standard uncertainty to the output uncertainty $\delta Q_{P E}$ is determined multiplying the estimation uncertainty of this parameter by its sensitivity coefficient:

$$
\begin{aligned}
& u_{V}\left(\delta Q_{P E}\right)=C_{V} \cdot u(V) ; \\
& u_{W}\left(\delta Q_{P E}\right)=C_{W} \cdot u(W) ; \\
& u_{Q}\left(\delta Q_{P E}\right)=C_{Q} \cdot u(Q),
\end{aligned}
$$

Using the standard uncertainty of the parameters and the sensitivity coefficients of Eq. (4), it is possible to re-formulate the equation for the squared standard uncertainty of the primary resource savings (Eq. (2)) as

$$
u_{c}^{2}\left(\delta Q_{P E}\right)=u_{V}^{2}\left(\delta Q_{P E}\right)+u_{W}^{2}\left(\delta Q_{P E}\right)+u_{Q}^{2}\left(\delta Q_{P E}\right) .
$$

To use Eq. (5) for calculating the uncertainties of the output quantity (primary resource savings) we have to know standard uncertainties for gas, heat energy and electricity consumption.

\section{STANDARD UNCERTAINTY OF INPUT PARAMETERS}

If it is impossible to repeat measurements or to perform statistical processing of the results, the uncertainty is called type B, and to estimate it a different kind of information is needed. In this case, the precision of the instruments is used, i.e. it is only possible to estimate the upper and lower limits of the sought-for quantity. Labelling the upper limit by $\mathrm{a}_{+}$and the lower limit by $\mathrm{a}_{-}$we obtain the best estimate of this quantity as 


$$
\text { best estimate }=\left(\frac{a_{+}+a_{-}}{2}\right) .
$$

If there is no additional information about the distribution of this quantity in the defined limits it is logical to assume that the factor values obey a uniform probability distribution, with the law of rectangular distribution being valid [6]. The density function for the law of rectangular distribution is:

$$
f(x)=\left\{\begin{array}{l}
\frac{1}{2 a} ;-a \leq x \leq a \\
0 ; \text { beyond the range. }
\end{array}\right.
$$

To determine the standard uncertainty, the expression for dispersion calculation is used:

$$
s^{2}=\int_{-\infty}(x-\mu)^{2} f(x) d x
$$

where $\mu$ is the average value of the quantity;

$x$ is the value of the quantity.

If the distribution density function is $f(x)=\frac{1}{2 a}$ and $\mu=0$, integrating Eq. (7) in the limits from $-a$ to $+a$ gives

$$
s^{2}=\frac{a^{2}}{3} \text {. }
$$

Then the standard uncertainty of the quantity is

$$
u=s=\frac{a}{\sqrt{3}} .
$$

In the case of a rectangular distribution the overlapping coefficient is $k=1.65$ and the expanded standard uncertainty is:

$$
U=1.65 \frac{a}{\sqrt{3}} .
$$

The rectangular distribution law can be applied when there is no other information than the interval of quantity changes. If it is known that the quantity values to be considered are located closer to the centre of this interval than to its boundaries, then the best model will be a triangular distribution. At the same time, if these values are located closer to the interval limits, the best model is the $U$-type distribution $[6,7]$.

Table 1 presents the estimates for the measured quantities of gas consumption, heat energy and electricity, the standard uncertainties, the sensitivity coefficients, and the contribution of each parameter's uncertainty to that obtained at 
determination of the primary resource savings. The estimates of the measured quantities are the 24-hourly indicators of a cogeneration plant's operation at the installed capacity. Their standard uncertainties are determined by Eq. (9) using the data on the precision of measuring devices. The sensitivity coefficients are calculated by formula (3). The contribution of each measured value to the uncertainty of that at determination of the primary resource savings is estimated using Eq. (4).

Table 1

Quantities and their characteristics used in the uncertainty analysis

\begin{tabular}{|l|c|c|c|c|c|}
\hline \multicolumn{1}{|c|}{ Quantity, $X_{i}$} & $\begin{array}{c}\text { Evaluation, } \\
x_{i}\end{array}$ & $\begin{array}{c}\text { Standard } \\
\text { uncertainty, } \\
u\left(x_{i}\right)\end{array}$ & $\begin{array}{c}\text { Sensitivity } \\
\text { coefficient, } \\
C_{i}\end{array}$ & $\begin{array}{c}\text { Standard } \\
\text { uncertainty } \\
\text { component, } \\
u_{i}\left(\delta Q_{P E}\right)\end{array}$ & $\begin{array}{c}\text { Input } \\
\text { index, } \\
\%\end{array}$ \\
\hline Gas consumption, $V, \mathrm{~m}^{3}$ & 1254 & 0.58 & -0.000589 & -0.00034 & 13.6 \\
\hline $\begin{array}{l}\text { Cogeneration } \\
\text { electricity, } W, \mathrm{MWh}\end{array}$ & 3.96 & 0.00058 & 0.1030 & 0.00006 & 0.4 \\
\hline $\begin{array}{l}\text { Cogeneration heat, } \\
Q, \text { MWh }\end{array}$ & 6.36 & 0.0162 & 0.052 & 0.00084 & 86 \\
\hline $\begin{array}{l}\text { Primary resource } \\
\text { savings, } \delta Q_{P E}, \%\end{array}$ & 25 & & & & \\
\hline $\begin{array}{l}\text { Standard uncertainty of primary resource savings, } u\left(\delta Q_{P E}\right)=0.00091 \\
\text { Expanded uncertainty of primary resource savings } U\left(\delta Q_{P E}\right)=0.0015 \\
\text { Relative uncertainty of primary resource savings } u_{r e l}\left(\delta Q_{P E}\right)=0.6 \%\end{array}$ \\
\hline
\end{tabular}

When reporting about the uncertainty of measurement results it is possible to use the relative uncertainty parameter $[8,9]$, which is calculated as

$$
u_{r e l}\left(\delta Q_{P E}\right)=\frac{U\left(\delta Q_{P E}\right)}{\delta Q_{P E}} .
$$

In this specific case, the relative uncertainty of the primary resource savings is $0.6 \%$, which means that at this plant under operating conditions the value of primary resource savings is $25 \pm 0.6 \%$ (that is, the savings are in the limits from $24.4 \%$ to $25.6 \%$ ). To estimate the uncertainty of primary resource savings for other operating conditions of the plant similar calculations have been performed (the results are shown in Fig. 2).

To suit the requirements on the uncertainty calculation and reporting [3], the primary resource saving should be shown as its quantity plus the expanded uncertainty of the quantity corresponding to a $95 \%$ probability. The measurements of the plant's operating data determine primary resource savings with the uncertainty shown in Fig. 3. For example, the calculated resource saving of $10 \%$ is determined with a relative expanded uncertainty $\pm 2 \%$ (which means that the primary resource savings are from $8 \%$ to $12 \%$ ). If there is strict demand that the primary resource savings should be no less than $10 \%$, then the calculated savings are to be $11.5 \%$ with an uncertainty of $\pm 1.5 \%$. Thus the primary resource savings will be from $10 \%$ to $13 \%$, which provides the minimally needed amount of savings. 


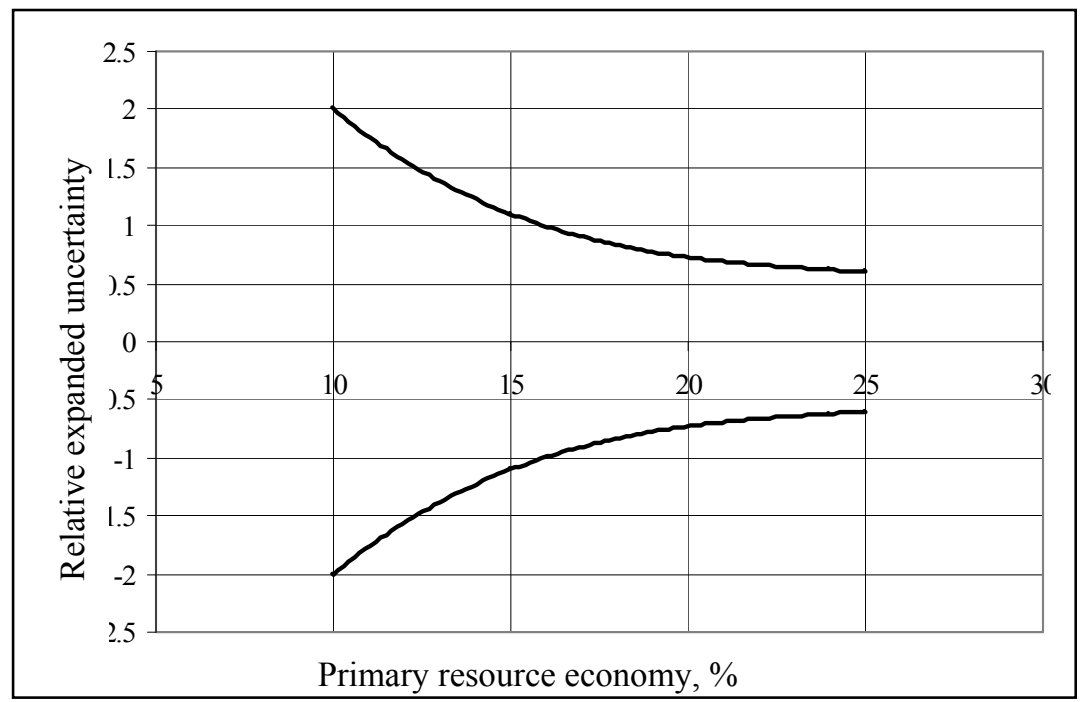

Fig.2. Dependence of expanded relative uncertainty on the plant's primary resource savings.

In general, it is evident that the primary resource savings are calculated with the uncertainty determined by that of the measured input quantities (gas consumption, cogeneration heat energy and electricity). At the considered cogeneration plant the uncertainty of the primary resource savings varied from $\pm 0.6 \%$ for the nominal load (savings $25 \%$ ) to $\pm 2 \%$ for the load with a primary resource saving of $10 \%$. The relationship between the primary resource savings and other operating parameters of the plant is shown in Table 2.

Table 2

Parameters of the cogeneration plant

\begin{tabular}{|l|c|c|c|c|c|c|c|}
\hline No. & $\begin{array}{c}\text { Gas } \\
\text { consumption, } \\
V, \mathrm{~m}^{3}\end{array}$ & $\begin{array}{c}\text { Heat } \\
\text { energy, } \\
Q, \\
\mathrm{MWh}\end{array}$ & $\begin{array}{c}\text { Electricity, } \\
W, \mathrm{MWh}\end{array}$ & $\begin{array}{c}\text { Plant } \\
\text { efficiency, } \\
\eta_{k o p}\end{array}$ & $\begin{array}{c}\text { Primary } \\
\text { resource } \\
\text { savings, } \\
\delta Q_{\mathrm{PE}}, \%\end{array}$ & $\begin{array}{c}\text { Plant } \\
\text { heat } \\
\text { load, } \\
q_{Q}\end{array}$ & $\begin{array}{c}\text { Expanded } \\
\text { relative } \\
\text { uncertainty, } \\
\pm U\left(\delta Q_{P E}\right), \\
\%\end{array}$ \\
\hline 1. & 1254 & 6.36 & 3.96 & 0.88 & 25 & 1.0 & 0.6 \\
\hline 2. & 1170 & 5.62 & 3.65 & 0.85 & 24 & 0.88 & 0.63 \\
\hline 3. & 933 & 3.816 & 2.29 & 0.7 & 10 & 0.6 & 2 \\
\hline
\end{tabular}

The savings depend on the amount of fuel consumed, and on the heat and electricity produced; these factors are affected by the plant's efficiency. The efficiency, in turn, is determined by the plant's operating with a full or partial load.

If the uncertainty of each input parameter is known, it is possible to make up a budget of the output data uncertainty. The uncertainty budget reflects the contribution of each input parameter uncertainty to that of output data. The uncertainty budget is described by Eq. (5) in which the squared standard uncertainty of the output quantity is determined as the sum of the squared standard uncertainties of the input quantities. It is impossible to calculate the standard uncertainty of the output quantity by merely summing the components of standard uncertainties of 
the input quantities. The square of a standard uncertainty possesses active properties that are not characteristic of a standard uncertainty itself. If we divide both sides of Eq. (5) by the squared standard uncertainty of the output quantity, with the result expressed in percent, we obtain:

$$
\frac{u_{V}^{2}\left(\delta Q_{P E}\right)}{u_{c}^{2}\left(\delta Q_{P E}\right)}+\frac{u_{W}^{2}\left(\delta Q_{P E}\right)}{u_{c}^{2}\left(\delta Q_{P E}\right)}+\frac{u_{Q}^{2}\left(\delta Q_{P E}\right)}{u_{c}^{2}\left(\delta Q_{P E}\right)}=100, \% .
$$

The ratios $\frac{u_{V}^{2}\left(\delta Q_{P E}\right)}{u_{c}^{2}\left(\delta Q_{P E}\right)} ; \frac{u_{W}^{2}\left(\delta Q_{P E}\right)}{u_{c}^{2}\left(\delta Q_{P E}\right)} ; \frac{u_{Q}^{2}\left(\delta Q_{P E}\right)}{u_{c}^{2}\left(\delta Q_{P E}\right)}$ are indices describing the contribution of the square of the quantity standard uncertainty component to the squared sum of total standard uncertainty emission. The corresponding index describes the role of uncertainty of each separate quantity in the total uncertainty budget [10]. The calculated values of indices are presented in Table 1. The primary resource saving budget is shown in Fig. 3.

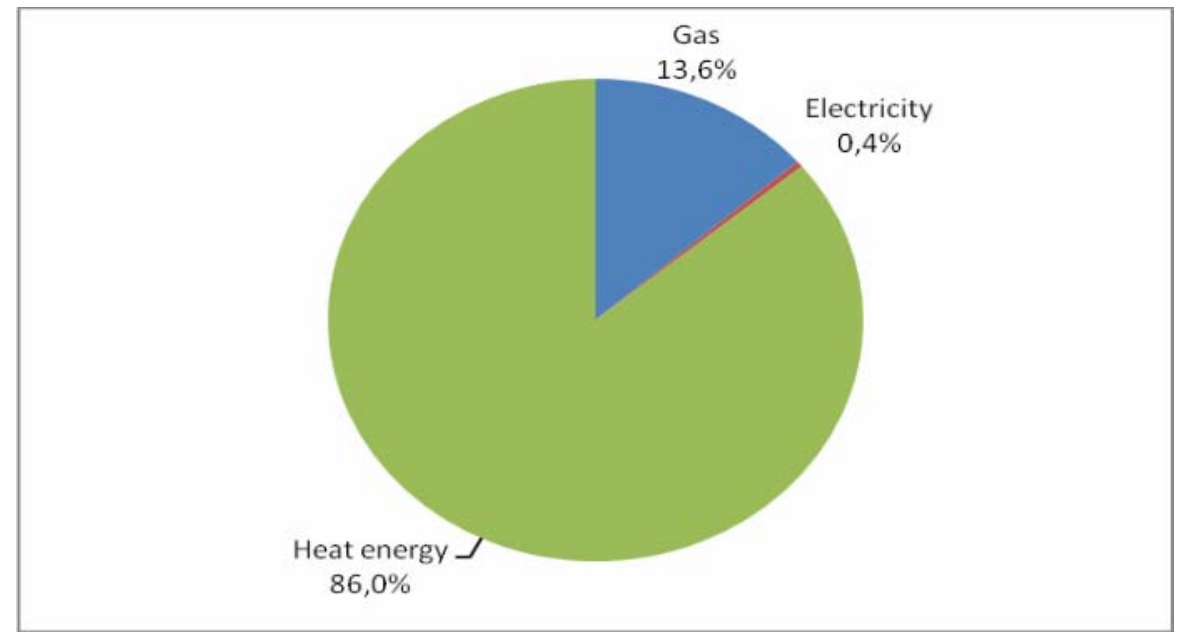

Fig. 3. Uncertainty budget of the primary resource savings.

\section{CONCLUSION}

In the work, it has been shown that the uncertainty index of gas consumption measurements is $13.6 \%$, that of electricity measurements $-0.4 \%$ and of heat energy $-86 \%$. The largest contribution to the uncertainty budget of the cogeneration plant's primary resource savings is made by the heat energy measurements. Therefore, to further reduce the total uncertainty the primary consideration should be given to this component. The least contribution to the total uncertainty budget is made by electricity measurements.

\section{REFERENCES}

1. LATAK - EA - 4/02.(2002). Mērījumu nenoteiktības noteikšana kalibrēšanā. 3. izdevums, 38 lpp.

2. Slajev, V.A. (2002). Recommendation on Application of the Document "Guide to the Expression of Uncertainty in Measurement in Russia. VNIIM (Russia), 7 p. 
3. International Organization of Standardization (ISO). (1993). Guide to the Expression of Uncertainty in Measurement. ISO, Geneva, Switzerland, 101p.

4. Romero Gonzales, M.L. (2004). Quality Assurance and the Evaluation of Uncertainties in Environmental Measurements. CIEMAT, Madrid (Spain), p. 10.

5. LATAK - D.036. (2005). Verificētu mērlīdzekḷu mērījumu nenoteiktības novērtēšana. 5 lpp.

6. Blumberga, M., Veidenbergs, I., Blumberga, D., \& Dadžāne, I. (2006) Energoavota kurināmā patēriña noteikšanas nenoteiktība. Latv. J. Phys. Tech. Sci. 3, 47-52.

7. Blumberga, M., Veidenbergs, I., \& Blumberga, D. (2006) $\mathrm{CO}_{2}$ monitoringa nenoteiktības analīze. Latv. J. Phys. Tech. Sci. 5, 37-45.

8. Rasmussen, S.N. (2006). GUM Workbench Specification. Danish Technological Institute, p. 4.

9. Kirkup, L. (2003). Calculating and Expressing Uncertainty in Measurement. University of Technology, Sydney (Australia), $27 \mathrm{p}$.

10. Castrup, H. (2004). Distributions for Uncertainty Analysis. Integrated Sciences Group, $12 \mathrm{p}$.

\section{KOĢENERĀCIJAS PRIMĀRO RESURSU IETAUPĪJUMU NENOTEIKTĪBAS ANALĪZE}

I. Veidenbergs, D. Blumberga, F. Romagnoli, E. Vīgants, M. Rošā

Kopsavilkums

Rakstā analizēti elektroenerğijas un siltumenerǵijas ražošanas mērījumu nenoteiktības rādītāji kog̣enerācijas stacijā. Analizēta ievaddatu ietekme uz primāro resursu ietaupījumu lielumu nenoteiktību. Veikta primāro energoresursu standartnenoteiktības un ieejas lielumu standartnenoteiktības izvērtēšana. Noteikts primāro energoresursu ietaupījumu nenoteiktības budžets.

06.10.2008. 